\title{
The Audit of the Financial System, Development and the Gaps in Albanian Businesses An over-view of PIFC Principles and Financial Management
}

\author{
Dr. Zaim Korsi \\ "Tirana University,Albania Director of Public Investments, EXC, Albania, Albanian Bussiness Investitor \\ Email:zaimkorsi@yahoo.com \\ Prof. Assoc. Dr. Alba Dumi \\ Dean of Graduated School, Ismail Qemali" Vlore University, Albania1 \\ Email: besi.alba@yahoo.com \\ Dr. Hava Mucollari \\ Accounting Expert, Tirana University Albania \\ Email:havamucolari@yahoo.com
}

\section{Doi:10.5901/mjss.2013.v4n10p209}

\section{Abstract}

Recently politicians and economists have often talked about structural reforms as the path toward sustainable economic growth. The implementation of the Competition Policy and Law is the most effective and less costly reform because its daily consistent implementation leads to direct benefits for businesses and citizens. The direct outcome of the implementation of this reform is increased market awareness, which, in turn, leads to increased efficiency in resource use by the society. The European Union has established, in the framework of Enlargement and the Public Internal Financial Control concept (PIFC), a set of principles in relation to sound financial management of public resources, resulting from both national and international financing. This set of principles is suggested to be followed and adhered to by the Republic of Albania in their relevant legislation and implementation. Internal Audit is present in Albania for developing this system. In the assessment carried out by the EU in July 2008, they identified that the internal audit law needed to be brought up to date in light of the PIFC requirements. Their main points were we are focus in this paper research are: 1.Over-lapping audit process between the High State Control and Internal Audit; 2. The audit of smaller entities should not be carried out by Albanian business. However if the audit work does not represent a considerable workload, the audit could be maintained in Albania at least as a temporary solution. The Albania government would be responsible for assessing the training needs, provide training and certification of internal auditors, including developing continuous training programs in Republic of Albania.

Keywords: Audit system, Albanian reforms, State control, Internal Audit

\section{Introduction}

In the process of its enlargement the European Union adopted the principles for sound financial management of the public funds, regardless if they come from an internal or international financing. It has been recommended these principles should also be laid down in the legislation of the member states and the candidates for accession. Following the recognition, at the Helsinki European Council in 1999, of Albania as a potential candidate for EU membership, the Republic of Albania has produced a National Strategy for Development and Integration (updated in 2008) and a Policy Paper on Public Internal Financial Control (PIFC) in 2005.

The increasingly large number of contacts between businesses and consumers and the Competition Institution in relation to market concerns or failure indications is a direct indicator of the achievement of objectives under that mission; this is at the same time the main challenge of our Institution. The improvement and sophistication of investigation tools and the reduction of investigation time characterized our activity in 2012, leading to an increased number of market interventions by the Competition Institution. 
The heads of central and local government institutions are responsible for setting up financial management and control system and the internal audit function within their organization. Some progress was made in strengthening the administrative capacity of the parliament Secretariat through training of staff and expert advice, including by international experts. A multiannual training strategy for the parliament's staff was adopted in May 2012. The unit for legal approximation in the parliament was strengthened by the hiring of a further adviser.

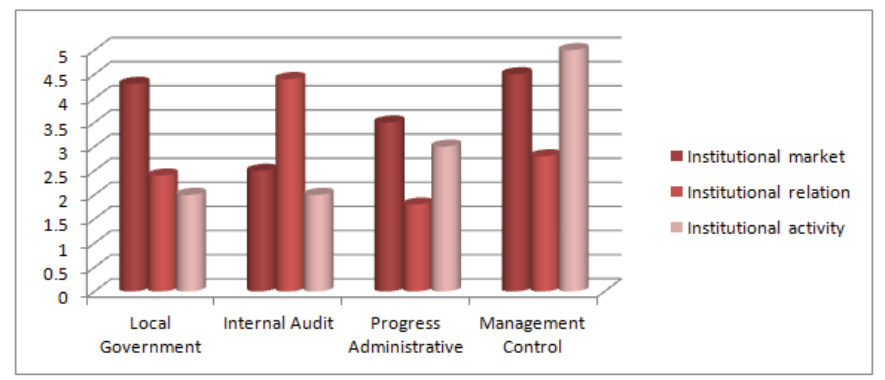

Graph 1: The heads of central and local government institutions, Source : Albanian Cl report 2011

The authorizing officers - are the highest ranked employees of general government units (central and local government institutions), responsible for planning, execution, performing financial management and control, monitoring, reporting, accounting and for responding to the recommendations made by internal audit and are accountable to the principle authorizing officer.

It is vital to the good functioning of the markets-which, in simpler words, means increased consumer wellbeingthat the justice system absorbs and conveys the philosophy of competition protection in the fairest manner possible. Not only is the reasoning of decisions in the light of the protection of public interest a legal obligation under the Law, but also, and above all, it is a moral duty since it affects the wellbeing of the citizens.

\subsection{Development in competition low and policy implementation}

The economic system in Albania is enshrined in Article 11 (1) of the Constitution, which specifies that the economic system of the Republic of Albania is based on private and public property, as well as on a market economy and on the freedom of economic activity. This constitutional principle is also ensured through the implementation of Law No. 9121 of 28 July 2003 "On Competition Protection," as amended, and the National Competition Policy. The responsible institution for its implementation is the Competition Authority. It operates pursuant to the Competition Law and Policy, in addition to public administration norms and best practices of European competition law.

The second level authorizing officers - are public administration employees in each dependent unit of central and local government institutions, responsible for planning, execution, internal financial control, monitoring, reporting, finance and accounting and for responding to the recommendations made by internal audit and are accountable to the authorizing officer.

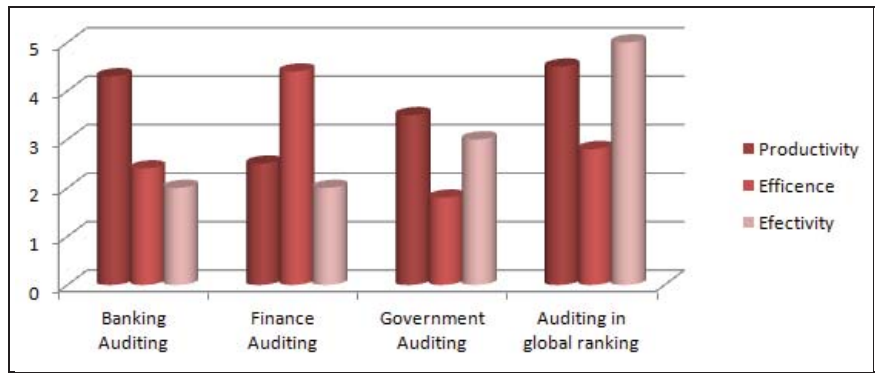

Graph 2 : The heads of central and local government institutions, Source : Albanian Cl report 2011 
The executing officers - are public administration employees of central and local government units, responsible for implementing financial management rules, keeping the accounts, and preparing management reports and financial statements and are accountable to the authorizing officer of the respective level.

\subsection{The internal auditors}

The internal auditors play an important role in the assessment of the effectiveness of the financial management and control systems. The internal auditor or the institution is responsible for internal auditing and should not be involved in the operational or in other activities than internal audit. He reports to the Authorizing Officer and Head of Institution. The external auditor (the High State Control) is responsible for the certification of public expenditure to the Albanian National Assembly. They may comment on the functioning of PIFC and report to Parliament if necessary, but the development and improvement of PIFC is the responsibility of government.

\section{Concept of public internal financial control}

Public Internal Financial Control includes the overall, consolidated system of control, based on internationally accepted standards, established and performed by the central and local government or by delegated organizations, in order to guarantee the sound financial management and control of the public funds. The PIFC system consists of three main pillars: Republic of Albania, The sound Financial Management and Control (FMC) systems, as a prime responsibility of managers of each public spending centre, with particular emphasis on minimum requirements of internal control. A functionally independent and objective Internal Audit (IA) service, supporting management and giving assurance and advice, that management and control systems are established in accordance with the rules and standards, and with the principles of sound financial management.

\subsection{Definition and types of foreign (debt) loans}

Recent years has almost no country which a good part of public expenditure not to finance with debt. Besides the different classifications, the debt can be classified as internal and external (on territorial source of the loan) debt that may be borrowed from the sources of Interior or by external financing sources, according to the duration can be short and long term. Public debt may be in cases when the state takes its place or borrow from abroad to finance their economic activities and private sector debt to finance their businesses. (Blake, R.R \& Mouton 1964)

The focus of our research will focus on the impact of the foreign debt in the economy of Macedonia, Kosovo and Albania. Through different periods of time, economists thought the loan has changed, some support the loan, arguing that represents an important source for a sustainable economic growth while another group what they see as harmful to the economy. Study of the effects of debt in the economy represents need, because the country through debt may accelerate the development process or alternatively to induce financial and economic damage the national economy. (Source: Albanian Progress Report 2011)

\subsubsection{The concept of borrowed money (Blake, R.R \& Mouton 1964)}

${ }^{1}$ Public debt represents the amount of borrowed money that the state owes the creditors at a given moment in time. Since our interest is in foreign loan, then we can define similarly the foreign loan-it represents the amount of money borrowed from foreign financial resources with the private sector the state owes to foreign creditors. In recent years there is an expansionary trend of debt in our country, in particular the public sector as a result of increased public spending, have equal opportunity and the private sector but not the same size. Central service in the Ministry of Finance (MOF),for developing and implementing a harmonized methodology and standardized quality of the FMC system and of the internal audit service. This will in turn ensure sustainability of existing training facilities. On the other hand, the PIFC must be seen in the context of the National Strategy for Development and Integration (NSDI). This paper of March 2008 replaces the previous National Strategy for Socio-Economic Development and sets out Albania medium-to-long-term national strategic priorities and goals.

\footnotetext{
${ }^{1}$ Bexheti Abdylmenaf, Public Finances, Tetovo, 2007, pg-370.
} 


\subsubsection{Control of Concentrations}

The control of concentrations is the third pillar of the Competition Protection Law, under which the Competition Institution supervises any changes to market structure. In order to increase the efficiency of law implementation, it continued to supervise any transactions carried out and filed with the National Registration Centre in 2012. Based on the close cooperation with the National Registration Centre, the Competition Authority has identified transactions in shares which had not been communicated to it, i.e. the undertakings involved in those transactions had failed to comply with their legal obligations to notify them.

Last year, the Competition Authority initiated four inspections of share transactions, of which two were cases of concentration with changes to the control structure. The acquiring undertakings which had violated the law for failure to submit a notification within one month were penalized with light fines (three cases of failure to submit timely notifications of transactions).( Bowers, D.G \& Seashore, 1966)

\subsection{Movements and the sizes of the loan in RM}

We can say that the trend of the kind of credit from abroad raises concerns for people who know well the effects of debt as it may adversely affect the economic stability of our country. External debt in comparison with the internal debt, represents the drag on to next generations, because the loan together with interest received must turn future generations, in If this loan is used for productive projects then burden for future generations may be less or maybe this debt will represent the benefit to them, depending on investment returns made with borrowed money.

Share the conviction that the debt represents an evil without which economies of many countries find it difficult to operate. Both the private sector and that public is needed loan when their costs exceed the financial revenues. This situation in economics is known as budget deficits when revenues exceed expenditures budget, here I want to emphasize that there is a distinction between debt and budget deficit, the debt represents the cumulative deficit by the time given.

Gross external debt (in\% of GDP)

\begin{tabular}{|l|l|l|l|l|l|l|l|}
\hline 2004 & 2005 & 2006 & 2007 & 2008 & 2009 & 2010 & 2011 \\
\hline 51.3 & 49.8 & 50.3 & 51.1 & 47.4 & 58.2 & 60.0 & 62.0 \\
\hline
\end{tabular}

Gross external debt (in million \$) If the supervision was carried out, further measures concerning execution in the state which passed the judicial decision shall be temporarily suspended.

The Administering State shall inform the Sentencing State on the supervision measures and on all circumstances that could lead to revocation of the suspended sentence, as well as on the expiration of the probation term.

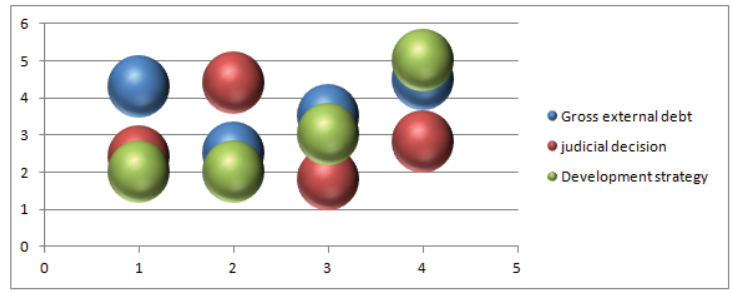

Graph 3: The Administering State shall inform the Sentencing State 2012 Source: www.nbrm.mk,

The right of the state which has imposed the judicial decision to enforcement shall finally cease if in the course of probation term none of the circumstances has occurred for which the suspended sentence should be revoked under its law

\begin{tabular}{|l|l|l|l|l|l|l|l|}
\hline 2004 & 2005 & 2006 & 2007 & 2008 & 2009 & 2010 & 2011 \\
\hline 2.080 & 2.528 & 2.503 & 2.841 & 3.304 & 3.780 & 4.133 & 4.874 \\
\hline
\end{tabular}

Source: www.nbrm.mk 


\subsection{The Maastricht criteria and GDP effects in Albanian PIFC system}

Under the Maastricht criteria, the total debt should not exceed 60\% of GDP, while the budget deficit could reach up to $3 \%$ of GDP. The following sections present the table in which we will see how it looks gross external debt of RM, from 20042011. This document (IFC) is a revised and updated version of the Policy Paper on Public Internal Financial Control (PIFC)) in the Republic of Albania, adopted by the Council of Ministers in June 2005.

The purpose of this document (IFC) is to describe the current Albanian PIFC system and the control environment and to determine the key directions and obligations of public sector units in Albania, in order to enable them to provide a reasonable assurance that public resources are managed with economy, efficiency and effectiveness. The main elements of the PIFC system in the Republic of Albania defined in the PIFC Policy Paper are: the financial management and control system (FMC), independent internal audit (IA), and a central coordination and harmonization service in the Albanian Ministry of Finance (MOF)

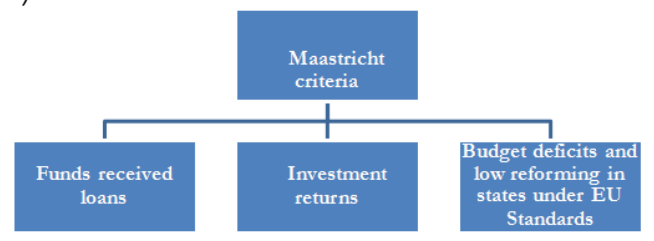

Tab 1 : Source: ${ }^{1}$ www. sitel.com.mk

The NSDI was agreed by the Strategic Planning Committee under the Integrated Planning System, which includes a set of operating principles to ensure that government policy, planning and implementation takes place in a coherent, efficient and integrated manner. The NSDI proposes a medium-to-long-term strategic planning process for 2007-2013 in conjunction with the introduction of a medium-term budgeting process,that requires each Government Ministry to develop 3-year budget planning.( Dansereau, F, Graen, G \& Haga, W.J.2011)

\subsection{Study on activity of foreign companies in the country, other legal aspects for study}

If we analyze foreign direct investment FDI will see that they have seen an upward trend for example if we analyze it in 1997 with the year 2005 will see a huge difference in 1997 they have reached a value of 141 million euro while in 2005 1769 million euro this difference is a result of the privatization of companies in the country (privatization of the country). (Ashby, W.R. Design for a brain. New York: Wiley, 1952.)

${ }^{2}$ As regards countries which have large investments in Macedonia can conclude that the leading terms of foreign investments in Macedonia are: Hungary, Greece, Netherlands, Switzerland and Cyprus (in 2005 with 66\% of total investments). The main sectors where these investments are concentrated by the said states are: Telecommunications, banking, financial services, trade, manufacturing (petroleum, textiles), construction, etc... In 2005 the net amount of profit from the investment of these countries amounts of 110 mil euro. Activities of larger companies are mostly focused on, the financial sector (banking sector participates with $90 \%$ of total activity in the financial sector), the telecommunication, manufacturing (refineries, textile, pharmacy, beverage), energy, construction, trade, these are sectors where large profits are realized.

\footnotetext{
${ }^{2}$ www.nbrm.mk Foreign investments and low improvements
} 


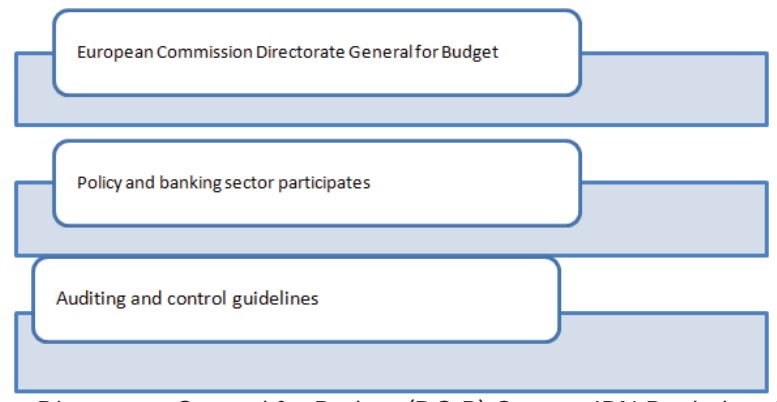

Tab 2: European Commission Directorate General for Budget (DG B) Source: IBN Bank data 2012

This PIFC Policy Paper includes also the concept of external audit and inspection (although they are not part of PIFC itself), as their influence on PIFC is significant in the Albanian context. The PIFC issues in Albania have already been an object of consideration and assessments of the European Commission Directorate General for Budget (DG B) These three pillars are underpinned by the principal of managerial accountability: the obligation of all managers in all public sector organizations to observe and apply the principles of sound financial management and legitimacy in the management of public funds. Ashby, W.R. Design for a brain. New York: Wiley, 1952.

Auditing and control guidelines for internal control standards in the public sector define internal control as:"an integral process that is effected by entity management and personnel and is designed to address risk and to provide reasonable assurance that in pursuit of the entity mission, the following general objectives are being achieved: 1 . executing orderly, ethical, economical, efficient and effective operations; 0 fulfilling accountability operations; 2. complying with applicable laws and regulations; 3 . safeguarding resources against loss, misuse and damage".

Internal control is a dynamic integral process that is continuously adapted to the changes an organization is facing. Management and personnel at all levels have to be involved in this process to address risk and to provide reasonable assurance of the achievement of the entity-mission and general objectives".

\subsubsection{Financial Control and general objectives, effectives and internal control.}

At the moment there is no clear process for assessing the effectiveness of internal control and reporting or escalating problems. Ideally each Ministry or local government unit should compile an annual statement on the effectiveness of internal control, highlighting any problems and giving examples of remedial action taken. While financial controls are strong, it is not clear whether they are cost-effective.

$\mathrm{H}$ 1. The benefits of controls should not outweigh the costs.

H 2: In public institutions the accounting systems are a little old-fashioned in that they are mostly paper-based. Staff use spreadsheets but what is needed is an financial system that interfaces appropriately with the new auditing method.

\section{Treasury financial modules}

The accounting system contains an accrual based chart of accounts, however at present it is not clear which controlling entities (budgetary and non-budgetary) will be consolidated into the controlling entity (Republic of Albania). The fixed assets are valued at their original cost and they have never been revaluated. This will be a major task in moving to international accounting standards, where revaluation of assets is a key requirement.

\section{Conclusion}

Albania has made much progress in the past three years with many changes introduced to Albanian public administration. Those changes helped to improve the functioning of Public Budgetary Organizations (Entities), and adjusting the laws and practices to international standards. Some of these implemented changes can be compared to best practices which are in force in the EU (for example, the new Management of Budgetary System Law and its references to internal control). Making changes demand not only institutional reforms - taking into consideration the recent rapid economic development of Albania - but also changes in culture and in the way civil servants perform their 
work. Albania will continue to develop Public Internal Financial Control in compliance with the EC requirements and international FMC and IA standards. Competition Law Implementation will development in this year. In 2013 the main priority for the Competition Authority work will be the protection and promotion of free and effective market competition through increased efficiency of market interventions, investigative tools and procedures for identifying and preventing cartels, abuse of dominant power and control of concentrations on the domestic market

The introduction of all these standards to the whole public administration in Albania is a necessary condition to recognize the observation of all legal norms and the EC requirements for the candidate countries intending to join the EU. The full activities of the Action Plan, has an exceptional importance in the achievement of a strong and adequate management and control system and internal audit function. The Action Plan also highlights areas where further technical support is required. The goal for the Competition Institution in 2013 will be to complete or continue conducting monitoring and inquiry and investigation cases that were initiated in the previous year, and read as best as possible all indications coming from complaints, the media, the business community or consumers

\section{References}

Ashby, W.R. Design for a brain. New York: Wiley, 1952.

Bagozzi, R.P. \& Yi,Y. On the evaluation of structural equation models. Journal of the Academy of Marketing Science,1988, 16(1),74-94 Bass, B.M Stogdill's handbook of leadership: A survey of theory in research. New York: Free Press, 1981.

Bass, B.M and Stogodill's handbook of leadership.Theory, research and managerial application (3rd ed) New York: Free Pass, 1990.

Blake, R.R \& Mouton, J.S. The managerial grid. Houston, TX: Gulf, 1964.

Bowers, D.G \& Seashore, S.E. Predicting organizational effectiveness with a four-factor theory of leadership. Administrative Science Quarterly, 1966, 11, 238-263.

Carmines, E.G. \& Maclver, J.P. Analyzing models with unobserved variables: Analysis of covariance structures. In G.W. Bohrstedt and E.F. Borgatta (Eds), Social measurement: current issues. Newbury Park,CA: Sage, 1981.

Conger, J.A. The dark side of leadership. Organizational Dynamics, 1993, 21, 46-58.

Dansereau, F,Graen, G \& Haga, W.J. A vertical dyad linkage approach to leadership within formal organizations: A longitudinal investigation of the function-making process. Organizational Behavior and Human Performance. 1975,13(1), 118-127.

Denison, D.R, Hooijberg, R..,\& Quin, R.E. Paradox and performance: A theory of behavioral complexity in managerial leadership. Organization Science. 6(5), 524-540. 